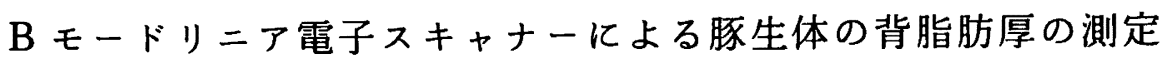

\author{
入江正和・西村和彦 \\ 大阪府農林技術センター, 羽曳野市 583
}

(1986. 6. 17 受付)

\begin{abstract}
要 約 小型軽量のリニア電子スキャナー（B モード超音波装置）を生体の豚の背脂肪厚の測定に 応用し，その利用性について検討した，70 頭の豚を用いて生体でさまざまな部位の背脂肪厚の超音波 測定を実施し, 屠殺後, 䋈垂状態の屠体実測値と比较した。リニア電子スキャナーは体軸に対して垂直 断面像を得ることができるだけでなく，正中線上の水平断面像もリアルタイムで画像化することができ るというすぐれた点があった．超音波断層像におけるさまざまな組織の判読は容易であった．皮庙およ び第一脂肪層と第二脂肪層の境界である結合組織の像は輝度が高く（白色）, 多重反射をおこしやすい 傾向にあった，第三脂肪首は第一，第二脂肪層と比较して不均一な輝度の高い断層像であった．中臂筋 は胸最長笳に比较して明瞙な輪郭をすつ輝度の高い像として観察された. 超音波測定値の再現性は良好 であったが, 肩の部位では若干低下した. 2 名の解析者による超音波測定値間の相関はすべての部位で

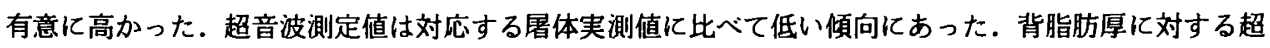
音波測定値と屠体実測値の相関は部位によって異なり，0.84 0.88 の範囲であった. 肩以外の各部位 における背脂肪厚の超音波測定値は互いに密接な関連があった. 以上のてとから，リニア電子スキャナ 一は生体での豚の背脂肪厚測定において実用的で有効な方法であると考えられた。
\end{abstract}

日畜会報，58(1)：44-52，1987

豚の背脂肪の厚さは重要な経済形質の一つであり, 枝 肉の格付検查や肉豚における赤肉量の予測，種豚の選抜 形質として利用されている.

豚の背脂肪厚を生体で予湘する方法については，さま ざまな方法が知られているが，超音波測定法は生体を傷 つけることなく実施できるすぐれた方法であり，装置の 改良ととあに多くの研究がなされてきだ.

初期に家畜に利用された超音波装置は一次元表示の A モードであったが, 装置の発達とともに断層像が表示で きる Bモード（手動式, 機械式）が主流となり, 現在, わが国においてあ豚産肉能力検定に機械式アーク走查方 式の超音波測定装置が利用されている2).

一方, 近年人体用の超音波装置の発達は著しく, 高機 能化や小型俥量化, 低価格化が進められ，ヒトではさま

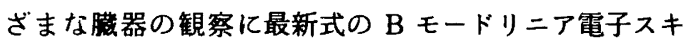
ヤナーか繁用されるようになってきだ．

著者ら ${ }^{4,5)}$ は、リニア電子スキャナーによる超音波断 屏法を繁殖豚の妊娠診断や繁殖障害豚の観察に利用して 実用的にすぐれた方法であるてとを示した．ての方法は 農家段階においても既に普及し始めているが，さらに豚
の背脂肪厚の測定に応用できれば利用価値が高まり，リ 二ア電子スキャナーはより有効な手段になるすのと思わ れる.

本試験は、リニア電子スキャナーを肉豚の背脂肪厚の 測定に使用し，その利用性について検討することを目的 とした。

\section{材料および方法}

供試動物は当センター産の 6 8 カ月齢, ランドレー ス種およびその一代雑種 70 頭（絶食前平均体重 96.2 $\mathrm{kg}$, 標準偏差 $14.2 \mathrm{~kg}$ ) である.

使用した超音波断首装置は，Bモードリニア電子夕 イプで既報) と同じあの（横河電機製作所製，U-SONIC mini, Model RT-30) である. 本装置は重量約 $5.5 \mathrm{~kg}$ と小型轻量で, 発信周波数 $3.5 \mathrm{MHz}$ のプローブを有し, リアルタイムで 5.5 インチのモニター上に画像(視野 85 $\mathrm{mm} \times$ 深度 $165 \mathrm{~mm}$ ) が得られる.

装置は携帯可能であり,フィールドにおける応用を考 虑して実験を行なった。超音波測定は単飼豚房内で，供 試豚を保定せずに起立させた状態で実施した。 
まず，皮庙と密着させるためにプローブに接触剤を塗 布し，各測定部位に体表面と直角となるような角度でプ ローブを接触させ，リアルタイムで得られた像を即座に 付属のポラロイドカメラで写真撮影した。なお,豚の被 毛はそらず,一部の豚は被毛をあらかじめ水でぬらした.

超音波測定部位は肩部 1 筒所, 体長 $1 / 2$ 部位 3 筒所, 腰部 3 箇所である. 肩部はできる限り正姿勢に近い状態 で正中線上（体轴水平方向）に沿ってプローブを置き, 体長 $1 / 2$ 部位は，できる限り春椎の棘突起が観察できる ような背正中線脊椎上と, 体の左側でロース（胸最長筋, $M$. longissimus thoracis) 断面が観察できるような 体軸垂直方向に，腰部は背の正中線上で中臂筋 $(M$. gluteus medius) 断面の前端之後端が観察できる 2 力 所にプローブを位置させた.

得られた断層写真 (実物の綐横の長さ $1 / 2$ ) から, 肩 部は脂肪のもっとす厚いとてろ (Shoulder), 体長 $1 / 2$ 部位脊椎上の断層像は, 棘乫起のエコーの間の部分

(1/2-vert. col.), 体長 1/2 部位で体軸に垂直な断層像 は背正中線から $2 \mathrm{~cm}$ 側位 $(1 / 2-2 \mathrm{~cm}$ lat.) と $5 \mathrm{~cm}$ 側位 $(1 / 2-5 \mathrm{~cm}$ lat.), 腰部は中箵 $(M$. gluteus medius）の前端（Loin 1）と中央部の薄い部分（Loin 2) および後端（Loin 3）の各脂肪厚をそれぞれ測定し た. Loin 2 以外の脂肪は各脂肪層 (第一脂肪層之第二 脂肪層）の厚さに分けて湘定した。装置の操作および断 層像の解积や脂肪厚の測定はすべて同一人物が行なった。

豚は超音波測定終了後，一日絶食させ，屠殺した。背 割り後, 左半丸を愁垂し, 温屠体の状態で脂肪厚の測定 を実施した，肩部は脂肪のもっとす厚いとてろ，背脂肪 は背中央部のもっとも薄いとてろ, 腰部はらんじる部 (中腎筋断面) の前端（頭側）と中央部および後端（尾 側)における脂肪厚を測定した.

なお, 屠体処理の関係等で, すべての個体についての 完全なデータは得られなかった。

また，装置の再現性を調べるために，16 頭の原を用 いて上記と同様の条件でそれぞれ測定を 2 回反復し, 得 られたデータから反復率の) と単相関係数を求めた. さら に，解析者の影響を調べるために，27頭の豚の同一の 記録写真を基にして, 別の解析者が各脂肪厚を測定し, 2 名の解析者の測定値間の単相関係数を求めた.

\section{結果およひ考察}

\section{1. 断層像の判読}

リニア電子スキャナーによって得られた超音波断層像 を図1〜4亿示す. 図 1 は肩部における正中線上, 図 2 は体長 $1 / 2$ 部位における正中線上, 図 3 は腰部における
正中線上, 図 4 は体長 $1 / 2$ 部位におりる正中線に垂直な 左側の各断層像である.いずれあ上から，皮咸，第一脂 肪層, 第二脂肪層…の順になっている. 各部位共, それ ぞれの組織の断層像の判読の仕方は同じであった。

皮唐は 3 5 mm の高い輝度を有する帯状の像として 観察された。皮庙之第一脂肪層との境界は多くの場合， やや不明瞭であった，乙れは，皮成のエコーが第一脂肪 層の像の中まで多重反射しているあのと考えられた。乙 のとき, 皮庙の厚さを過大に，第一脂肪層を過少に判読 してしまう恐れがあるため判読にあたっては注意が必要 であった。

背脂肪は第一脂肪首，第二脂肪首ともに同じような低 い輝度の像として観察された。両脂肪層の境界は高輝度 の線状の像としていずれの場合でむ明確に観察すること ができた．乙の境界は多くの場合，多重反射によって第 二脂肪層内に輝度の低い不明瞭な虚像を生じた（図 2). 第二脂肪層と第三脂肪層あるいは筋層との境界す明暸で あった．したがって虚像が存在するものの画像の判読は やさしく，第一脂肪層と第二脂肪層の厚さを測定するの は容易であった。体長 $1 / 2$ 部位脊椎水平像（図2）にお ける脂肪層は, 棘乫起のエコーによって厚さが不均一に なるが，その間の部位は比較的均一な層として観察する ことができた.

第三脂肪層は，第一，第二脂肪層よりも輝度の高い帯 状の像として観察されたが, 内部の輝度は必ずしも高く はなく，均一ではなかった（図 4). 特に薄い第三脂肪 層では，像が得にくかった。

筋肉組織の像は部位により異なっていた。すなわち， ロースは，第一，第二脂肪層と同じような輝度で不均一 な像を示した（図 4) が，腰部における中靔筋は第一， 第二脂肪層よりあ不均一な輝度の高い像として観察され た（図3)。ロースの輪郭は明暸でなかったが，中腎筋 の輪郭は明瞭で形状は実際の半丸枝肉断面と同じような 半月形を呈した.

骨は超音波を反射してしまうために像としては得られ ず, 棘突起 (図 1，2）, 尾椎 (図 3), 助骨 (図 4) 共不 明瞭であった。

断層像の判読上で気をつけなければならないのは，多 重反射エコーであるが, 組織境界等の結合組織は通常輝 度の差によって見分けがつく，皮庙は実像と同じような 輝度の虚像を生じやすいため, 一定の厚さ（実測では 3 〜 $5 \mathrm{~mm}$ ) をむつあのとして測定する方がよいかもしれ ない.

同じ脂肪層でも第一，第二脂肪層之第三脂肪層は輝度 の差が異なるが, 乙れは, 組織境界の多重反射エコーと 
化学的組成の差が主な原因と考えられる.脂肪層の化学 的組成㲹つて MOODY and ZOBRISKY ${ }^{7)}$ は, 第一脂肪 首之第二脂肪層の化学的組成はほとんど変わらないが, 第三脂肪層はそれら皮下脂肪層よりも水分およびその他 の成分が多く, 粗脂肪分が少ないと報告している.

2. 再現性之解析者間の差

表 1 にリニア電子スキャナーによる豚背脂肪厚測定の 再現性と解析者間の差を反復率と単相関係数を用いて示 した.

\section{1）再現性}

超音波測定を2回絽返した結果, 反復率は肩部第一脂肪 層が 0.86 で，その他の部位は 0.9 以上の高い値を示し， 単相関係数もすべて有意な $(\mathrm{p}<0.01)$ 高い値を示した.

肩部におりる再現性は他の部位と比べてやや劣り，乙 れは肩部の脂肪が第一に豚の姿勢によって変化しやすい ためであり，特に頭部を持上げた場合は最大脂肪厚は正 姿勢よりも增大する．また，肩部における脂肪層の厚さ はかなり不均一で, 組織構造の複雑なととも影響し, 必 ずしも同一の部位を測定しているとは限らないためであ ると思われる. 豚の姿勢の影畫は保定によって避けられ るあのであるが，時間と手間を必要とする.

体軸に平行な断面像，特に棘突起の断面像を得るため プローブを正確に位置付けることはややむずかしく，位 置や角度に若干のずれはあったものと思われるが，再現 性は高く，精度に大きな影㸷を与えるものではなかった。

垂直断面像を得るにあたっては, プローブ表面が平面 的であるため, 断層像が欠りないように体表面に密着さ せるためには強く押しあてる必要があった．てのため， 再玩性は高かったものの正中線側位では組織の変化によ る若干の測定誤差があるかもしれない。

一般的に超音波法による脂肪厚の測定の再現性の高い ことはいくつかの報告 ${ }^{6,8-10)}$ で認められている. MERSMANN $^{6)}$ は体長 $1 / 5$ 部位（肩）と $3 / 4$ 部位（腰） で体長 $1 / 2$ 部位よりあ反復率が劣り，乙れは肩と腰が複 雑な組織構造をしているためであるとしている．本研究 における腰部での測定値の再現性が高いのは, リニア電 子スキャナーの水平断面像によって中等筋を探し出し， 解剖学的に同一部位を測定するととができるからと思わ れる. WEBB ${ }^{10)}$ は，背正中線 $6.5 \mathrm{~cm}$ 側位では肩や $1 / 2$ 部位よりも腰部（中軗筋上）の方が反復率が高かったと 報告している.

2）解析者間の差

脂肪厚に対する 2 名の解析者による超音波測定値の相 関係数（表 1）は，いずれの部位のどの組織においても 0.90 以上の有意に（p<0.01）高い値を示した. A 飞
対する B の回帰直線の傾きも 0.90 1.05 で有意に 1 と 異ならなかった。とのととからりニア電子スキャナーに よる豚脂肪厚の測定は解析者の差がはとんどない方法で あると考えられる.

初期の頃の実験で, COOK and CuTHBERTSON ${ }^{\text {(1) }}$ はA モードと B モード各 3 機種の超音波装置を比校し，装 置間の差はほとんどなかったが，オペレーターによる差 が方法の有効性を左右するほど大きく，正確な判読が必 要であると報告している.

近年において, SATHER ら ${ }^{120}$ は A モード2機種を比 較し，オシロスコープ表示の装置 (Krautkramer USM 2）では判読に熟練が必要で，むしろテテジタル表示の 簡易背脂肪超音波装置（Scanoprobe $731 \mathrm{~A}$ ) の方が判 読誤差が少かったと報告している.デジル表示の A モード装置は，携帯型で取扱いが簡単でフィールドでも 利用できるというメリットはあるが, 脂肪の付着は部位 によって異なるため, 複数回測定する必要があり, 各脂 肪層の区別はできない.

GILES ら ${ }^{13)}$ は A モード (Scanoprobe 731) ではオ ペレーターの経験が精度に影響するとし，B モードの 機種（Scanogram 731）の方が正確であったと報告し ている. KEMPSTER ら ${ }^{10}$ の 4 つのさまざまなタイプの 装置を比較した実験では，装置間の精度に差はほとんど なかったものの，A モードよりあ B モードの法が良い と報告している. 得られる情報が多い分だけ $\mathrm{A}$ モード よりあ Bモードの方がすぐれていると思われる.

同じ B モード装置です，家畜で広く実用化されてい るアーク走查方式は，広範囲な像を得るのに適している が，走查にやや時間がかかり，体轴に平行な像を瞬時に 得ることはできない.

一方, リ二ア電子走查方式は, 特定の組織を輝度の差 をつけて矓時に表示することができる. このため，断層 像の判読の誤りはかなり少なくなる. また垂直断面像だ けでなく，水平断面像を得るてとができるため得られる 情報がより多く, 再現性が高くなる，リアルタイム装置 の短所は，画質の良くないとと，視野の狭いてとである が，脂肪層の測定にはほとんど支障とならない。

3. 超音波測定値と屠体実測値の関係

表 2 亿各部位のそれぞれの組織における超音波測定値 と屠体実測値の関係を示した。

部位間では肩がもっとも厚く, 中腎筋前端, 後端の順 で，いずれも第二脂肪層の影響が大であった．体長 $1 / 2$ の各部位では第一脂肪層の変化はみられなかったが，第 二脂肪層は側位になるにつれて減少した。しかし，第三 脂肪層を含めた総脂肪厚ではあまり变化がなかった。 

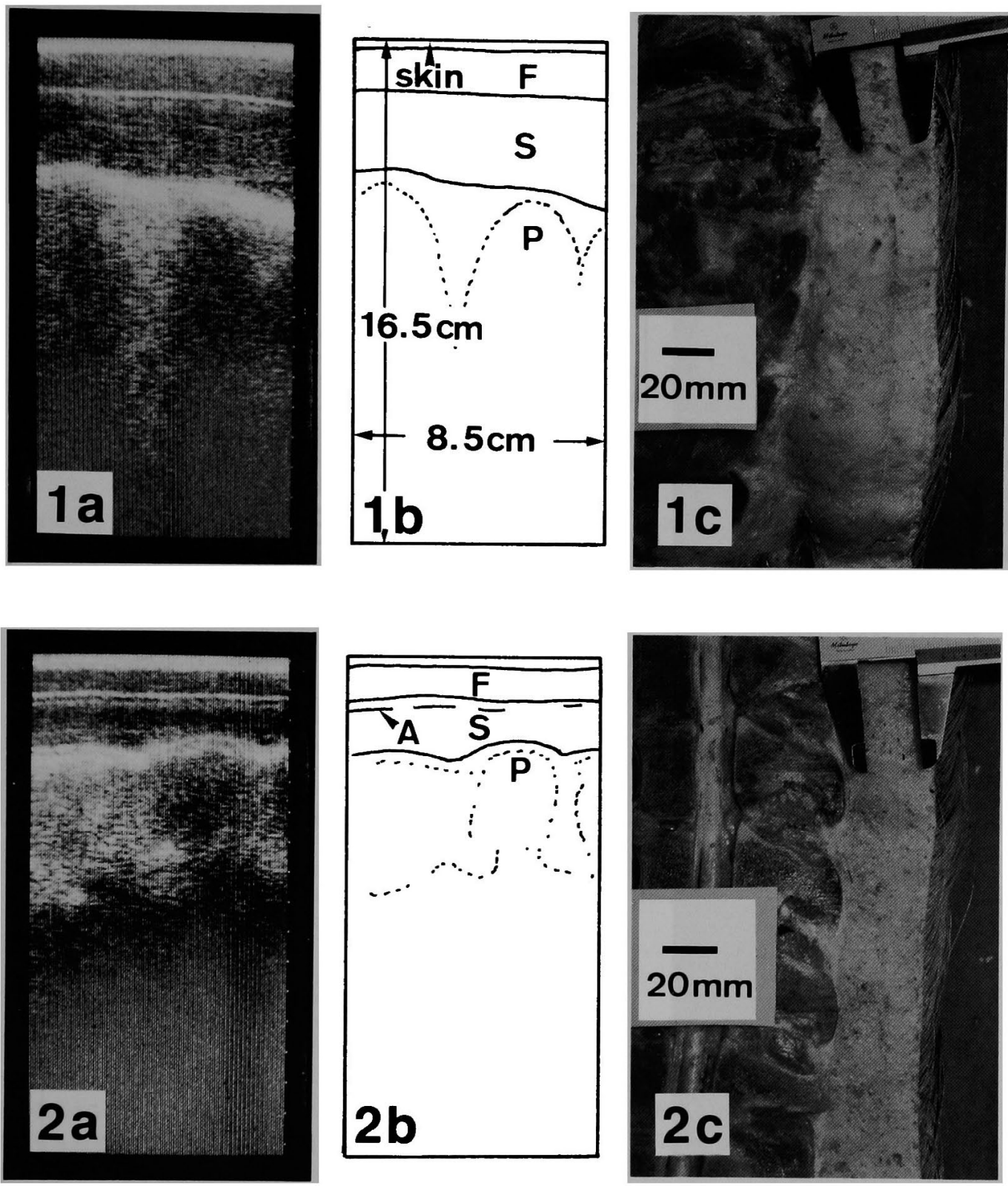

Fig. 1. Backfat at the shoulder over the vertebral column of the midline of a pig. Figs. 1 a, b and $c$ are an ultrasonogram taken by the B-mode linear electronic scanner, a diagram and the photograph of the longitudinal sectional cut of the left carcass suspended by the leg, respectively. F, first layer of backfat ; S, second layer of backfat : P, Processus spinosus.

Fig. 2. Backfat at the midback over the vertebral column of the midline of the pig. Figs. 2 a, b and $\mathrm{c}$ are an ultrasonogram, a diagram and a photograph of the longitudinal sectional cut, respectively. A, artifactual echo produced by multiple reflections. 

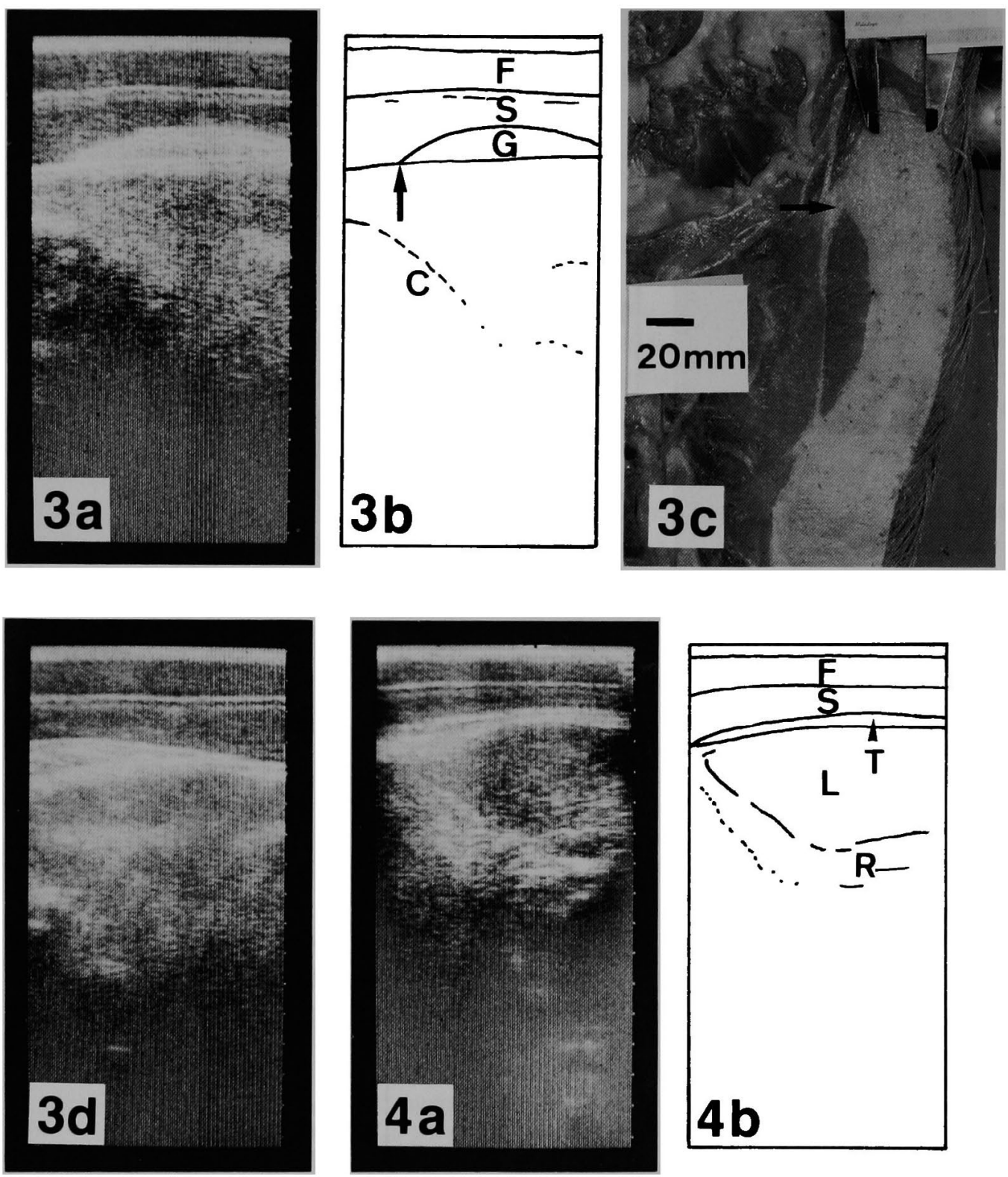

Fig. 3. Ultrasonograms ( $a$ and d), the diagram (b) and the photograph of the longitudinal sectional cut (c) at the loin. The posterior edge of the $M$. gluteus medius is shown by arrows in Figs. $3 \mathrm{~b}$ and $\mathrm{c}$ and its anterior edge is observed in Fig. $3 \mathrm{~d}$. G, $M$. gluteus medius; C, Coccygeal vertebrae.

Fig. 4. Ultrasonogram (a) and the diagram (b) of the cross section at $1 / 2$ body length. T. third layer of bakfat; L, M. longissimus thoracis; R, rib. The pig used for Figs. 3 and 4 is the same animal as was used for Figs. 1 and 2. 
Table 1. Differences between repeated measurements and two interpreters for ultrasonic variables of backfat thickness $(\mathrm{mm})$ on pigs

\begin{tabular}{|c|c|c|c|c|c|c|c|c|c|c|c|c|c|c|}
\hline \multirow{2}{*}{\multicolumn{2}{|c|}{ Variable Layer ${ }^{1}$}} & \multicolumn{7}{|c|}{ Difference between repeated measurements } & \multicolumn{6}{|c|}{ Difference between two interpreters } \\
\hline & & \multicolumn{2}{|c|}{$\mathrm{n}^{2)}$ Mean 1} & \multirow{2}{*}{$\frac{\mathrm{SD}}{1.6}$} & \multirow{2}{*}{$\frac{\text { Mean } 2}{11.1}$} & \multirow{2}{*}{$\frac{S D}{2.5}$} & \multirow{2}{*}{$\frac{\text { Repeat }^{3)}}{.86}$} & \multirow{2}{*}{$\begin{array}{l}\mathrm{r}^{4)} \\
.78\end{array}$} & \multirow{2}{*}{$\frac{n}{27}$} & \multirow{2}{*}{$\frac{\text { Mean A }}{12.0}$} & \multirow{2}{*}{$\frac{S D}{2.6}$} & \multirow{2}{*}{$\frac{\text { Mean B }}{11.7}$} & \multirow{2}{*}{$\frac{S D}{2.4}$} & \multirow{2}{*}{$\frac{\mathbf{r}}{.96}$} \\
\hline Shoulder ${ }^{5)}$ & $\mathbf{F}$ & 16 & 10.9 & & & & & & & & & & & \\
\hline & $\mathrm{S}$ & 16 & 19.8 & 4.2 & 19.5 & 4.0 & .91 & .82 & 27 & 20.4 & 5.0 & 20.1 & 5.3 & .99 \\
\hline & $\mathbf{T}$ & 16 & 30.6 & 5.2 & 30.6 & 5.6 & .94 & .88 & 27 & 32.3 & 6.8 & 31.9 & 6.9 & .99 \\
\hline \multirow[t]{3}{*}{$1 / 2-$ midline ${ }^{6)}$} & $\mathbf{F}$ & 16 & 7.1 & 1.7 & 7.0 & 1.6 & .98 & .96 & 27 & 7.4 & 1.5 & 7.5 & 1.5 & .90 \\
\hline & $\mathbf{S}$ & 16 & 8.7 & 2.5 & 8.8 & 2.0 & .96 & .94 & 27 & 10.4 & 3.6 & 10.5 & 3.3 & .98 \\
\hline & $\mathrm{T}$ & 16 & 15.8 & 3.7 & 15.8 & 3.2 & .97 & .95 & 27 & 17.8 & 4.9 & 18.0 & 4.5 & .98 \\
\hline \multirow[t]{3}{*}{$1 / 2-2 \mathrm{~cm}$ lat. ${ }^{7)}$} & $F$ & 16 & 6.4 & 1.5 & 6.4 & 1.5 & .98 & .96 & 27 & 7.3 & 1.7 & 7.3 & 1.7 & .92 \\
\hline & S & 16 & 5.7 & 2.1 & 5.7 & 2.1 & .97 & .94 & 27 & 6.4 & 2.7 & 6.6 & 2.8 & .98 \\
\hline & $\mathrm{T}$ & 16 & 13.8 & 3.8 & 14.2 & 3.7 & .98 & .96 & 27 & 16.2 & 4.8 & 16.2 & 4.7 & .97 \\
\hline \multirow[t]{3}{*}{$1 / 2-5 \mathrm{~cm}$ lat. ${ }^{8)}$} & $\mathbf{F}$ & 16 & 7.0 & 1.1 & 6.9 & 1.2 & .90 & .80 & 27 & 7.5 & 1.8 & 7.5 & 1.8 & .92 \\
\hline & $\mathrm{S}$ & 16 & 5.1 & 2.3 & 4.9 & 2.2 & .98 & .96 & 27 & 5.3 & 2.1 & 5.3 & 2.3 & .96 \\
\hline & $\mathrm{T}$ & 16 & 13.6 & 4.0 & 13.6 & 4.0 & .98 & .96 & 27 & 14.9 & 4.1 & 14.6 & 4.1 & .98 \\
\hline \multirow[t]{3}{*}{$\operatorname{Loin} 1^{91}$} & $\mathbf{F}$ & 16 & 9.3 & 2.4 & 9.3 & 2.5 & .99 & .97 & 27 & 10.2 & 2.4 & 10.5 & 2.5 & .96 \\
\hline & $\mathbf{S}$ & 16 & 11.5 & 3.3 & 11.3 & 3.1 & .97 & .95 & 27 & 12.3 & 3.6 & 12.3 & 3.4 & .98 \\
\hline & $\mathbf{T}$ & 16 & 20.8 & 5.4 & 20.6 & 5.3 & .99 & .98 & 27 & 22.5 & 5.5 & 22.7 & 5.4 & .97 \\
\hline Loin $2^{10)}$ & $\mathrm{T}$ & 16 & 16.6 & 5.1 & 16.5 & 4.8 & .99 & .99 & 27 & 16.3 & 4.8 & 16.0 & 4.7 & .98 \\
\hline \multirow[t]{3}{*}{ Loin $3^{111}$} & $\mathrm{~F}$ & 16 & 9.9 & 2.8 & 9.8 & 2.7 & .99 & .97 & 27 & 9.5 & 2.6 & 9.8 & 2.6 & .95 \\
\hline & $\mathrm{S}$ & 16 & 13.7 & 4.1 & 14.0 & 3.9 & .99 & .98 & 27 & 12.9 & 4.3 & 13.1 & 4.4 & .98 \\
\hline & $\mathrm{T}$ & 16 & 23.6 & 6.4 & 23.8 & 6.2 & .99 & .99 & 27 & 22.5 & 6.5 & 22.8 & 6.6 & .98 \\
\hline
\end{tabular}

1) Backfat layers indicated as $F$, first layer; $S$, second layer; $T$, total thickness. $T$ at $1 / 2$ lat. include also third layer.

2) Number of animals.

3) Repeatability obtained from one-way analysis of variance with each animal used as a treatment group. Repeatability $=\left(\sigma^{2}\right.$ animal $) /\left(\sigma^{2}\right.$ error $+\sigma^{2}$ animal $)$.

4) Simple correlation coefficient.

5) The maximum measurement on the midline of the shoulder.

6) $1 / 2$ body length over vertebral column of midline.

7) $1 / 2$ body length over $2 \mathrm{~cm}$ lateral to the vertebral column.

8) $1 / 2$ body length over $5 \mathrm{~cm}$ lateral to the vertebral column.

9) Anterior end of the $M$. gluteus medius on the midline.

10) The minimum measurement above the $M$. gluteus medius.

11) Posterior end of the $M$. gluteus medius on the midline.

平均値において屠体実測値は対応する部位の超音波測 定値よりあ常に 1 6 $\mathrm{mm}$ 高い值を示し, 全般的に, 第 一脂肪層よりあ第二脂肪層の方が差が大きかった．測定 部位は両者で必ずしも一致するあのではないが, 解剖学 的部位が一致するとみられる腰の部位においても超音波 測定値の方が低い傾向にあった。

超音波測定値が屠体実測値よりも低い値を示すととは 他の報告6,9,15-18) とも一致しており，超音波法が正確で ないということではなく，生体で起立している状態と紫 垂された屠体の状態といった測定条件の差が大きいすの と考えられる. 三上らッは超音波測定値と屠殺直後の卧
せた状態の実測値との相関は 0.96 と高く，㦟垂した状 態の実測値との相関は 0.88 であったと報告している.

超音波測定値と屠体実測値の相関係数は第一脂肪層が $0.66 \sim 0.77$ で，第二脂肪層が $0.77 \sim 0.88$ で，総脂肪厚 では 0.84 0.88 の範囲であった．第一脂肪首の相関係 数が低かったのは標準偏差からあ分かるように個体間の 差の少ない脂肪首だからである. 同一個体においてす第 一脂肪層は第二脂肪層に比較するとかなり均一な厚さの 脂肪層であった.

背脂肪厚に対する生体での超音波測定值と屠体実測値 との相関について GiLLIS ら ${ }^{15)}$ がまとめたとてろによる 


\section{入江・西村}

Table 2. Means, standard deviations, ranges and correlation coefficients for carcass and ultrasonic variables of backfat thickness $(\mathrm{mm})$ on pigs

\begin{tabular}{|c|c|c|c|c|c|c|c|c|c|c|}
\hline \multirow[b]{2}{*}{ Variable $^{11}$} & \multirow[b]{2}{*}{ Layer } & \multicolumn{4}{|c|}{ Carcass } & \multicolumn{4}{|c|}{ Ultrasonic } & \multirow[b]{2}{*}{$\mathbf{r}$} \\
\hline & & $\mathrm{n}$ & Mean & $\mathrm{SD}$ & Min.-Max. & $\mathrm{n}$ & Mean & SD & Min.-Max. & \\
\hline \multirow[t]{3}{*}{ Shoulder } & F & 62 & 12 & 3 & $7 \sim 18$ & 70 & 11 & 2 & $7 \sim 16$ & .77 \\
\hline & $S$ & 62 & 23 & 6 & $13 \sim 43$ & 70 & 20 & 5 & $11 \sim 36$ & .77 \\
\hline & $\mathrm{T}$ & 62 & 35 & 7 & $22 \sim 55$ & 70 & 31 & 6 & $18 \sim 46$ & .84 \\
\hline \multirow[t]{3}{*}{ 1/2-midline } & F & 70 & 8 & 2 & $4 \sim 11$ & 70 & 7 & 1 & $4 \sim 11$ & .72 \\
\hline & $\mathrm{S}$ & 70 & 11 & 3 & $5 \sim 21$ & 70 & 10 & 3 & $4 \sim 19$ & .88 \\
\hline & $\mathrm{T}$ & 70 & 19 & 4 & $10 \sim 29$ & 70 & 17 & 4 & $9 \sim 28$ & .87 \\
\hline \multirow[t]{3}{*}{$1 / 2-2 \mathrm{~cm}$ lat. } & $\mathrm{F}$ & - & - & - & -- & 67 & 7 & 1 & $5 \sim 10$ & - \\
\hline & $\mathrm{S}$ & - & - & - & $-\quad-$ & 67 & 7 & 2 & $3 \sim 14$ & - \\
\hline & $\mathrm{T}$ & - & - & - & $-\quad-$ & 67 & 17 & 4 & $8 \sim 26$ & - \\
\hline \multirow[t]{3}{*}{$1 / 2-5 \mathrm{~cm}$ lat. } & $\mathrm{F}$ & - & - & - & $-\quad-$ & 67 & 7 & 2 & $4 \sim 11$ & - \\
\hline & $\mathrm{S}$ & - & - & - & $-\quad-$ & 67 & 6 & 2 & $3 \sim 11$ & - \\
\hline & $\mathrm{T}$ & - & - & - & -- & 67 & 16 & 4 & $8 \sim 26$ & - \\
\hline \multirow[t]{3}{*}{ Loin 1} & $F$ & 68 & 11 & 2 & $7 \sim 17$ & 68 & 10 & 2 & $5 \sim 15$ & .66 \\
\hline & $\mathrm{S}$ & 68 & 18 & 5 & $9 \sim 29$ & 67 & 14 & 4 & $7 \sim 22$ & .82 \\
\hline & $\mathrm{T}$ & 68 & 29 & 6 & $17 \sim 42$ & 67 & 23 & 6 & $13 \sim 36$ & .88 \\
\hline Loin 2 & $\mathrm{~T}$ & 23 & 18 & 6 & $8 \sim 31$ & 24 & 17 & 7 & $7 \sim 27$ & .91 \\
\hline \multirow[t]{3}{*}{ Loin 3} & $\mathrm{~F}$ & 42 & 11 & 2 & $6 \sim 17$ & 36 & 8 & 2 & $6 \sim 14$ & .74 \\
\hline & $\mathrm{S}$ & 42 & 16 & 5 & $9 \sim 27$ & 36 & 12 & 4 & $6 \sim 23$ & .80 \\
\hline & $\mathbf{T}$ & 42 & 27 & 7 & $18 \sim 44$ & 36 & 20 & 6 & $12 \sim 37$ & .85 \\
\hline
\end{tabular}

1) See footnotes to table 1.

Table 3. Correlation coefficients among positions of ultrasonic variables of backfat thickness on pigs

\begin{tabular}{|c|c|c|c|c|c|c|c|c|c|}
\hline Variable $^{11}$ & Layer & 1. & 2. & 3. & 4. & 5. & 6. & 7. & 8. \\
\hline 1. Shoulder & $\mathrm{T}$ & & & & & & & & \\
\hline 2. $1 / 2$-midline & $\mathrm{T}$ & .74 & & & & & & & \\
\hline 3. $1 / 2-2 \mathrm{~cm}$ lat. & $F+S$ & .67 & .84 & & & & & & \\
\hline 4. & $\mathrm{~T}$ & .68 & .83 & .97 & & & & & \\
\hline 5. $1 / 2-5 \mathrm{~cm}$ lat. & $F+S$ & .63 & .81 & .87 & .86 & & & & \\
\hline 6. & $\mathrm{~T}$ & .68 & .82 & .84 & .88 & .91 & & & \\
\hline 7. Loin 1 & $\mathrm{~T}$ & .68 & .78 & .77 & .79 & .78 & .79 & & \\
\hline 8. Loin 2 & $\mathrm{~T}$ & .56 & .87 & .91 & .91 & .92 & .88 & .97 & \\
\hline 9. Loin 3 & $\mathrm{~T}$ & .76 & .84 & .88 & .85 & .83 & .80 & .91 & .95 \\
\hline
\end{tabular}

1) See footnotes to table 1.

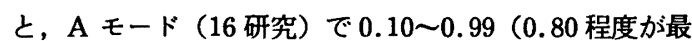
多), B モード (1 研究) 0.67 と報告している. B モ一 ドについては他にあいくつかの報告 ${ }^{18,19,20)}$ があり, 0.6 $\sim 0.9$ 程度である. 相関は測定部位や測定条件によって かなり異なるものであるが, リニア電子スキャナーによ る方法は他の装置と同程度であると考えられる。

4. 測定部位
表 3 に各部位における総脂肪厚の超音波測定値間の相 関を示す. 部位間の脂肪厚はいずれあ有意に（p<0.05） 高い相関を示した. しかし, 肩と他の部位の相関は他の 部位間の相関にくらべて全般的に低い值を示した.てれ らの結果の傾向は MERSMANN ${ }^{21)}$ の報告と一致している. $1 / 2$ 部位における 3 䇢所の測定値間の相関は高く、い ずれの䇢所を選んで個体間の脂肪厚の大小を比较しても, 
結果の㑯向は変わらないあのと思われる. しかし, 総脂 肪厚は変化が少ないものの, 各脂肪層の変化は大きく （表 2), 測定部位の異なるデータの比较は好ましくない と考えられた.

全般的な相関の高さから考えて, 肩以外の部位では 1 箇所だけの娜定値でも個体の脂肪度を反映するかすしれ ない. KEMPSTER and EVANS ${ }^{22)}$, KEMPSTER ら ${ }^{200}$ は赤 肉割合を予測するのに適切な 1 䇢所の脂肪厚を測定すれ ばさらに測定箇所をふやしてあ予測精度の向上は望めな いとのべている.

脂肪厚の測定は，枝肉ではその断面，つまり正中線で 測定されてきたが, 超音波法ではほとんどの場合, 正中 線側位が利用されてきた. てれは, 正中線では棘突起が 存在するために正確な值が得にくいためである.しかし， 正中線側位といっても何 $\mathrm{cm}$ 側位にするかは研究者に よってかなり開きがあり, わが国の産肉能力検定のため の超音波測定 ${ }^{2}$ では体長 $1 / 2$ 部位 $2 \mathrm{~cm}$ 側位が利用され ている. 各国で剆定部位が異なるため, FORTIN ら ${ }^{10)}$ は 適正な測定部位と位置を検討し, 正中線上の最後助骨〜 その $10 \mathrm{~cm}$ 前方が変異が少なかったと報告している.

生体で正中線上の脂肪厚を簡単に測定できるととは他 にもメリットがある. 商品価値を左右する枝肉の格付は, 半丸断面，つまり正中線の脂肪厚（わが国では第 9 13 胸椎間, アメリカ ${ }^{20}$ では第 1 胸椎, 最後胸椎, 最後腰 推一本試検の Loin 2, 他化カナタ ${ }^{25}$, EEC の大半 ${ }^{22}$ ) を参考として実施しており, 生体で脂肪厚を知るてとが できれば，農家は出荷前に眗養管理によって脂肪厚を調 整し，上物率の向上を計れる可能性がある.

わが国の産肉能力検定においてあ枝肉の脂肪厚は, 肩 のもっとも厚い部位, 背のもっとも薄い部位（本試験の 体長 $1 / 2$ 部位周忍), 腰のあっとも厚い部位（概して中 等筋周包) が測定されており, 正中線の脂肪厚は選抜形 質としてあ利用されている.

以上の結果から，豚の背脂肪厚測定におりるリニア電 子スキャナーの利用は実用的で有効な方法であると考え られる. 今後さらに他の超音波装置であ実施されている ようなロース断面積の測定に応用できるかどうか検討す る必要があると思われる.

\section{文献}

1) STOUfFer, J.R., Techniques and Procedures in Animal Science Research. 212-214. American Society of Animal Science. New York. 1969.

2）宮沢一男, 脈産肉能力検定のための超音波測定機
器使用の手引. 日本種豚登録協会. 東京. 1979.

3）北村次男,リニア電子スキャンのための腹部局所 解剖. 秀閪社. 東京. 1982.

4）入江正和 - 大本邦介- 能谷重夫，日畜会報， 55 : 381-388. 1984.

5）入江正和・西村和彦, 日畜会報, 57 :288-293. 1986.

6) Mersmann, H.J., J. Anim. Sci., 54:268275. 1982.

7) Moody, W.G. and S.E. Zobrisky, J. Anim. Sci., 25 : 809-813. 1966.

8) Stouffer, J.R., M.V. Wallentine, G.H. Wellingoton and A. Diekmann, J. Anim. Sci., $20: 759-767.1961$.

9）三上仁志・甲斐勝利・佐藤 勲・阿部猛夫，日畜 会報, 45：381-386. 1974.

10) WebB, A.J., Anim. Prod., $20: 433-436$. 1975.

11) Cook, G.L. and A. Cuthbertson, Anim. Prod., 9: 278. 1967.

12) Sather, A.P., H.T. Fredeen and A.H. Martin, Can. J. Anim. Sci., $62: 943-949$. 1982.

13) Giles, L.R., R.D. Murison and B.R. Wirson, Anim. Prod., $32:$ 47-50. 1981.

14) Kempster, A.J., A. Cuthbertson, M.G. Owen and J.C. Alliston, Anim. Prod., $29:$ 175-181. 1979.

15) Gillis, W.A., G.H. Bowman, H. Greiger and G.W. Rahnefeld, Can. J. Anim. Sci., $52: 637-644.1972$.

16) Fortin, A., D.W. Sim and S. Talbot, Can. J. Anim. Sci., 60:635-641. 1980.

17) Fredeen, H.T. and G.M. Weiss, Can. J. Anim. Sci., 61 : 319-333. 1981.

18) Jones, S.D.M., O.B. Allen and C.R. Haworth, Can. J. Anim. Sci., $62:$ 731-738. 1982.

19）宮沢一男・营野幸基・田畑正彦，日豚研誌，14： 63-71. 1977.

20) Mersmann, H.J., J. Anim. Sci., $54: 276-$ 283. 1982.

21) Mersmann, H.J., J. Anim. Sci,, $58: 324-$ 334. 1984.

22) Kempster, A.J. and D.G. Evans, Anim. Prod., 28: 87-96. 1979.

23) Kempster, A.J., J.P. Chadwick, D.W. Jones and A. Cuthbertson, Anim. Prod., $33: 319-324.1981$.

24) NPPC, Procedures to Evaluate Market Hogs. National Pork Producers Council. Iowa. 1976.

25) Fortin, A., Meat Sci., $10: 131-144.1981$. 


\title{
Ultrasonic Measurement of Backfat Thickness \\ in Live Pigs by the Use of the B-mode \\ Linear Electronic Scanner
}

\author{
Masakazu IRIE and Kazuhiro NISHIMURA \\ Livestock Division, The Osaka Agricultural \\ Research Center, Habikino-shi 583
}

The usefulness of the portable linear electronic scanner (B-mode ultrasonic machine) was evaluated for measuring the backfat thickness of live pigs. In 70 pigs, ultrasonic measurements of different parts of the live animals were compared with the direct measurements of the carcass. The linear electronic scanner had the advantage of being able to display not only vertical cross-sectional images of the body axis but also horizontal ones on the midline at real time. It was easy to identify the images of different tissues on the ultrasonograms. Both the skin and the connective tissue between the first and second fat layers showed echogenic (white) images which produced multiple reflections. The image of the third fat layer was more echogenic and irregular than the first and second fat layers. Compared with the $M$. longissimus thoracis, the $M$. gluteus medius was visualized as a sharply outlined echogenic image. The repeatability for the various ultrasonic measurements was acceptable but it was slightly lower for the shoulder than for the $1 / 2$ body length and the loin. The correlation coefficients between ultrasonic measurements obtained by two interpreters were highly significant $(p<0.01)$ in all parts examined. The ultrasonic measurements had the tendency to be lower than the corresponding carcass measurements. The correlation coefficients between ultrasonic and carcass measurements of backfat thickness ranged from .84 to .88 depending on the parts. The ultrasonic measurements of backfat thickness in the different parts, except the shoulder, weve closey related. These results indicate that the linear electronic scanner was a practically useful method for measuring the backfat thickness of live pigs.

Jpn. J. Zootech. Sci., 58 (1): 44-52, 1987

Key words : ultrasonic, electronic scanner, backfat, fat thickness, pig 